合成アジュバントによるリンパ節・ 脾肉芽腫性炎形成に打ける胸腺の役割 小橋 修・小沢 敦*, 小谷尚三**

\section{medical topics}

Role of thymus for MDP-induced granuloma formation in lymph nodes and spleen

Osamu Kohashi - Atsushi Ozawa*, Shozo Kotani**

慢性肉芽腫性炎の発症機序に関して, 免疫アレルギー 反応，特飞遅延型過敏反応 (DTH) が重要な役割を果た していることが知られている。この主張は, 蛋向抗原を アジュバントに混ぜ動物に免疫し，关の蛋白抗原に対し てDTH が成立しているときにのみ肉芽腫性炎ができた といら事実にもとついている。ここ使われたアジュ・゙ ントの最小有效構造は, N-アセチルムラミルジペプチド (MDP) である.MDPをw/oエマルジョンの型でラッ 卜足らら皮下に 1 四注射することにより，典型的な肉芽 腫性炎が所属リンパ節をはじめ，脾，肝にできる。この MDP には抗原性がなく，MDP に対するDTH 子認め られない，さらに興味あることは，先天的胸腺欠損ヌ一 ドラットに打いても上記の慢性肉芽腫ができることであ る。この抗原性のない合成アジュバンド MDP による畏 芽腪性炎形成に扮ける胸腺の役割について, ヌードラ ト扰よびそのへテロラットでの成續を述べる。

\section{方 法}

動物は, 実中研由来の $\mathrm{rnu} / \mathrm{rnu}, \mathrm{rnu} /+$ ラット雌装 6〜8 週秢を用いた。動物はすべてビニルアイソレータ の中で SPF 環境下に飼育した、MDP は第一製楽より 供与を受けた，MDP 所定旦をPBS に溶かし，同量の Difco 不完全アジュバントとともに w/o エマルジョン を作製し，その $0.05 \mathrm{ml}(100 \mu \mathrm{g})$ をラット左下肢足う ら皮下に注射した。注射後 $1 \sim 4$ 週目に夰 3 匹ずつェー テル麻酔下に殺し諸葴器を採取し，ホルマリン洞定後， HE 染色を行い, 病理学的検討をした。刘照としてMDP を含まない不完全アジュバント（w/o）のみ老注射し， 同様の組織学的検討をした。

\section{成 績}

MDP 注射群で, $100 \%$ 飞 rnu/十 ラットはアジュバ ント関節炎を発㹥したが，先天的湖腺火損ヌードラット および対照群は発皿しなかった。阅節炎は, 注射後10日 前後より四肢関節周囲の発赤腫朖を認女急速に増恶し, 観察期閌中注添同程度の関節炎がつづき, 徐々に急性炎 症は消能し，あとに慢性の骨関節周井の腫脹を残した。

組織学的にも, 臨床経過と泟添平行した変化が認めら れ, 初期の急性浸出性炎が淂液膜, 骨軟骨部, 腱靴周用

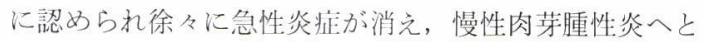
移行した。ささて所属りンバ節の反応は, 注射後 2 週目 をピークに典型的な類上皮細胞肉芽腫が $\mathrm{rnu} /+, \mathrm{rnu} /$

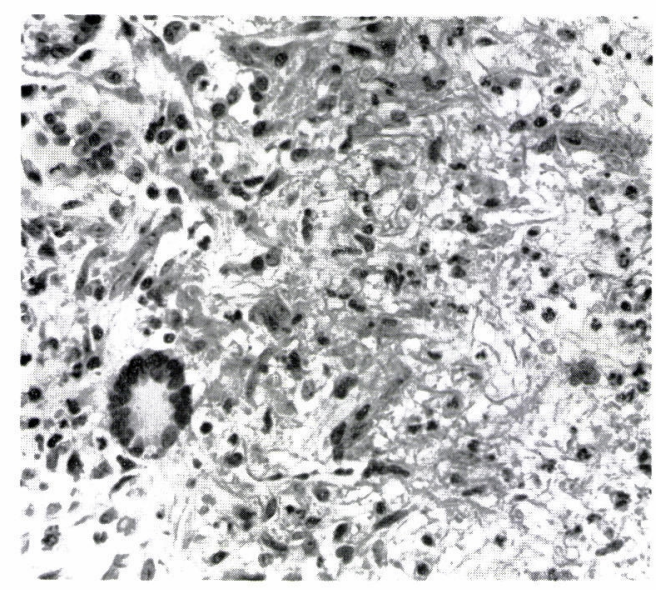

図 1

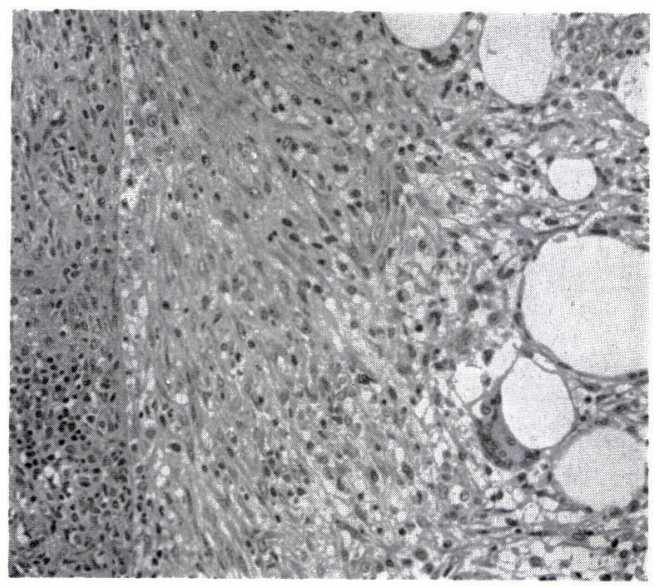

図 2

rnu ラットとともに認められた（汹 1)。ただ両群の差 は, rnu/十 ラットでは大きな epithelioid granulomaの 中心部に大きな necrosis がでさ，そこに多数の多形核 白血球 (PMN) の浸潤がみられたことである。新生児期 胸腺 $(\mathrm{rnu} /+)$ を $\mathrm{rnu} / \mathrm{rnu}$ ラットの腎被膜直下に移相 した場合にはちょうど中間の epithelioid granuloma が認められた。肉芽腫内には区核細胞の浸潤がともに認 められた。対照群の不完全アジュバント注射群では油滴 の久で肉芽腫形成はなく，肉芽腫形成にはMDP 分子が 百要であることが示唆された。肝には小さい focal gra nuloma が形成され，rnu/ + に強く, rnu/rnu ではより 小さく，かつまれに観察された。脾には $\mathrm{rnu} /+, \mathrm{rnu} /$ rnu ともに capsulitis が認められ，网 2 のよらに典型的 な肉芽腫を形成していた。

結 語上嗼の granuloma 形成には胸脌の関与な しにできること，MDP のアジュバント活性が車要で抗 原性の関与は無視できることが小されれた。

* Department of Microbiology, Tokai University School of Medicine 束海大学学部微生物学教室

** Department of Microbiology, Osaka University Dental School 大阪大学附学部細菌学教窒 